\title{
Problem-Based Learning with the Gamification Approach in Ecopedagogy for Children Aged 4-7 Years: A Case Study of Kampung Kramat Malang, Indonesia
}

\author{
$1^{\text {st }}$ Habib Syafi'udin \\ Department of Instructional Technology \\ Universitas Negeri Malang \\ Malang, Indonesia \\ habib.syafiudinbaru@gmail.com
}

\author{
$2^{\text {nd }}$ Nova \\ Universitas Negeri Malang \\ Malang, Indonesia
}

\author{
$3^{\text {rd }}$ Dedi Kuswandi \\ Universitas Negeri Malang \\ Malang, Indonesia
}

\begin{abstract}
Environmental damage has become a serious problem of the world today. Eco-Pedagogy is essential for early childhood to raise awareness, role, and involvement in addressing environmental issues. The study aims to develop a problem-based learning method with gamification in Eco-pedagogy to provide environmental knowledge and environmental awareness through informal early-childhood education. The subject is children aged 57 years in Kampung Kramat Malang, Indonesia (a slum on the riverbank and built on the public cemetery, which has been transformed into a thematic tourism village in Malang). This study is a research and development using the ADDIE (Analysis, Design, Development, Implementation, and Evaluation) development model with qualitative and descriptive data analysis techniques. The results showed that the problem-based learning instructional design with gamification approach can provide the environmental awareness on children's cognitive and habituation.
\end{abstract}

Keywords: problem based learning, gamification, Ecopedagogy, children aged 4-7 years

\section{INTRODUCTION}

Environmental damage has become a serious problem of the world today. Cities continue to grow with a good economy despite urbanization leading to even the destruction of natural resources, climate change and other environmental issues. It also poses social challenges such as poverty, inequality and separation that arise everywhere [1]. Indonesia is the world's second largest country that produces 187.2 million tons of plastic waste [2]. Most Indonesia's rivers are heavily polluted and the piped water management is unreliable [3]. It takes effort to raise environmental awareness, one of which is through the environmental education that involves understanding, emotion and behavioral change [4]. In general, the environmental problems in this disruption era can be solved with eco-pedagogy.

The concept of eco-pedagogy was introduced by Paulo Freire as a transformation-based education model with the aim of helping to uncover the environmental problems with collective problems in the community [5], [6]. It was created as a critique of social issues arising from various environmental harmful acts [7]. Eco-pedagogy also emphasizes the main causes and effects of environmental problems to critically understand how nature should be treated [8]. Besides, it plays a role in concern for the environment through knowledge, values, and habituation [5]. Thus, ecopedagogy is very important to be given in addressing complex environmental issues today.

In this case study, the researchers developed an ecopedagogy design for children aged 4-7 years in the Kampung Kramat Malang. This slum is located behind a cemetery on the edge of Brantas River, which was transformed into a thematic village in 2017. Then, this study developed the problem-based learning model with a gamification approach as an effort to address the environment issues in Kampung Kramat Malang.

Historically, problem-based learning was developed in the 1960s at the McMaster Medical School to produce graduates who could think critically and solve increasingly complex medical problems [9]. Problem-based learning is a model that increases engagement and stimulates learning based on problems and critical thinking. In line with eco-pedagogy, problem-based learning also involves children's participations with the same objective, namely solving surrounding problems to make education more meaningful [10].

On the other hand, an authentic approach needs to be considered to develop the problem-based learning model for children aged 4-7 years because they have unique characteristics. It is necessary to accommodate their growth needs by gamification, which is a combination of $21^{\text {st }}$ century learning contents, literacy and skills in creating a learning environment [11]. Gamification is how the "games" mechanism or elements in "games" integrated into traditional non-games works to provide a more engaging experience and motivation, 
In general, the characteristics of pre-school children can be involving the learners and creating a meaningful learning [12][13]. The use of gamification can be a solution to the problems of learning environments and flipped classrooms, such as lack of motivation and interest [14]. This method can also train students' critical-thinking skills and increase their interest in the lesson [15]. Gamification makes children more motivated and actively learning in a pleasant atmosphere, so their learning outcomes are relatively increased [16].The gamification features are abstracted reality, goals, rules, reward structures, conflict, competition, cooperation, time, feedback, levels, storytelling, player interest, aesthetics, and replay or do over [17][15]. The most used elements are feedback, goals, badges, leader board, point system, and levels [18]. All these features are to achieve the interest, engagement and motivation in the learning process.

Based on the explanation, in this study, eco-pedagogy for children aged 4-7 years began with the environmental problems in Kampung Kramat-Malang, plastic waste. Then, problembased learning and gamification were the relevant approaches used for pre-school children in Kampung Kramat Malang.

\section{METHOD}

This research is a development study using the development model of ADDIE (Analyze, Design, Development, Implementation, Evaluation) [19]. At the analysis stage, the researchers did field observation in Kampung Kramat. At the design stage, we formulated learning objectives based on the analysis and determined the evaluation technique. At the next stage, we developed the design of learning related to the material, strategy and approach in order to achieve the learning objectives formulated. Then, the design was implemented. An important step of ADDIE is the evaluation stage, conducted in media validation, content validation and field trials. Another evaluation in the final stage related to the students' achievements and learning interests was conducted through the questionnaire, observation and interview to the students and parents.

\section{RESUlTS AND DiSCUSSION}

The study resulted in the eco-pedagogy design product for children aged 4-7 years with the gamification problem-based learning approach developed in the ADDIE model. Kampung Kramat Malang is the suburb of Brantas in Sukun district, Malang. It is populated by around 450 people working as the grave-diggers and small merchants. This village has been transformed into a thematic tourism village [20]. One of the environmental problems is the plastic waste. Most suburbans along the riverbank consider the river as the most practical dumpsite, so they are accustomed to throwing the garbage there [21]. In the area of Malang, the improper waste disposal system comes from the attitude of the people who throw garbage in open areas such as rivers despite many negative environmental impacts, such as contamination of surface water, groundwater, and soil [22]. dentified from their development stages on emotions, physical and cognition. According to the social development of the children aged 4-6 years, they begin to understand the rules, obey them, play with peers and understand the rights of others. In this stage, a child has been able to feel proud, shamed and guilty. This is the age of maximum physical growth, while their cognitive is at a pre-operative level (only able to understand visual objects) [23]. In Kampung Kramat Malang, the children have a low learning motivation and have not yet been involved in overcoming the environmental problems. The environmental issues raised in this study are about the plastic waste, the plastic waste types, the awareness of the waste disposal, and the river cleanliness. It is hoped that this learning can improve the students' achievements in their affective, cognitive and psychomotor aspects.

The researchers developed the problem-based learning model with gamification approach through images, video, audio, role-play strategy, storytelling and so on. Learning activities are divided into three, namely: opening, core activities and closing. In core activities, the researchers developed the problem-based learning model in four phases. The design is described in detail through the following diagram in Figure 1.

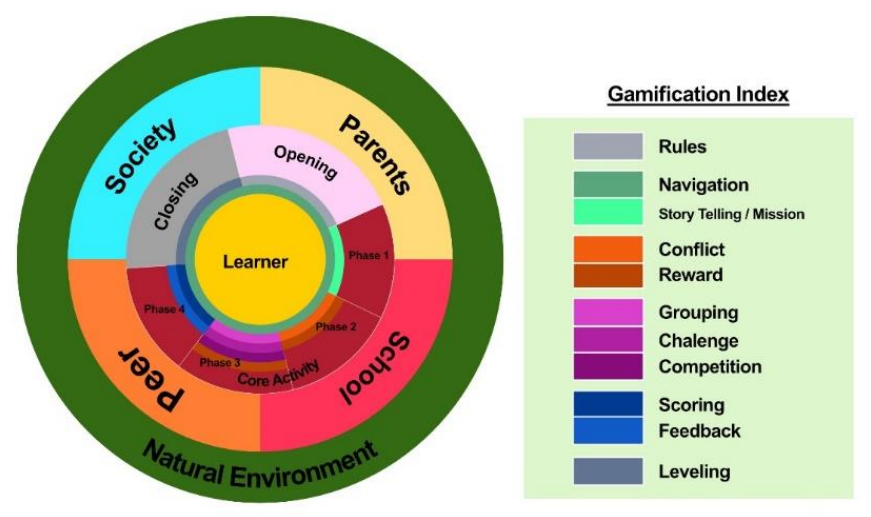

Fig. 1. Problem-Based Learning with gamification approach design

Furthermore, the learning media was implemented informally in the children aged 4-7 years in Kampung Kramat Malang in five meetings for a month $(60$ minutes in each meeting). The next stage was evaluation including field trials, content validation, and media validation. Field trials have been formulated to measure the students' interest, involvement and motivation, problem-solving skills, and material mastery Validations is done by experts and practitioners; this instructional design development is already considered feasible in learning. The validation results can be seen in table 1 . 

FOR CHILDREN AGED 4-7 YEARS

\begin{tabular}{|c|c|c|c|c|c|c|}
\hline No & Indicator & Validator 1 & Validator 2 & Validator 3 & Average & Category \\
\hline 1. & Instructional design & 3,25 & 4 & 3 & 3,42 & Good \\
\hline 2. & Media Accessibility & 4 & 3,50 & 3,25 & 3,58 & Good \\
\hline 3. & $\begin{array}{l}\text { Instructional resources for teaching } \\
\text { and learning }\end{array}$ & 3 & 3 & 4 & 3,33 & Good \\
\hline 4. & Interaction and community & 4 & 4 & 3 & 3,67 & Good \\
\hline 5. & Strategies used & 4 & 3,50 & 3 & 3,50 & Good \\
\hline 6. & $\begin{array}{l}\text { Media suitability with early } \\
\text { childhood characteristics }\end{array}$ & 4 & 4 & 3 & 3,67 & Good \\
\hline 7. & Assessment of learning & 3 & 3 & 3 & 3,00 & Good \\
\hline \multirow[t]{3}{*}{8.} & Parental involvement & 3 & 3 & 3 & 3,00 & Good \\
\hline & Average & 3,53 & 3,50 & 3,16 & & \\
\hline & Overall Average & & & & 3,40 & Good \\
\hline
\end{tabular}

\begin{tabular}{|l|l|}
\hline Score & Category \\
\hline 4 & Excelent \\
\hline$\geq 3$ & Good \\
\hline$\geq 2$ & Poor \\
\hline$\geq 1$ & Bad \\
\hline
\end{tabular}

In this study, the feasibility of a minimum set value of "good", If the results of the final assessment (overall) at least got an "good" by experts and practitioners, the instructional design of the development is already considered feasible in learning

The instructional design cannot be separated from the learning characteristics and theory. The characteristics of the students have been discussed and the underlying learning theory of the problem-based learning is the constructivist theory. The bases of the constructivist theory are (1) learning as the result of the personal interpretation of experience, (2) learning as an active process occurring in realistic and relevant situations, and (3) learning as the result of an exploration of multiple perspectives [24].

These make the instructional design focus on meaningful learning, real-life learning, active learning, contextual learning and collaborative learning [24]. As a center point, the students are expected to provide new maturation to contribute to peers, families, school society, and, more broadly, natural environments (eco-pedagogy purpose). These elements play a role in building the students' emotions, moods, and motivations to learn. Therefore, they need to be considered in preparing the learning design [25].

Moreover, the learning activities consist of three sections i.e. opening, core activities and closing as described in Figure 1.

\section{A. Opening}

Pre-school learning should not neglect opening activities. In this design, the opening activities are done by marching, singing, greeting and other activities. The gamification features, which are a distinctive pattern, consist of the rules and navigation. The rules are the granting of the agreement while the approval realizes through choosing the picture (agree or disagree). The rules provision is precisely given to children as mentioned by Stanrock [26] that the pre-school children have begun to understand the rules.

At the opening activities, the whole class activities always use the navigation feature. Navigating means pointing the direction. In most games, people use navigation to control the menu, back, and home buttons. Thus, the gamification provides the symbol and color that will be touched by the children as a form of engagement and involvement. The navigation menus provided are "Start", "Stop", and "Next".

\section{B. Core Activity}

In core activities, the problem-based learning scenario is implemented with a gamification feature approach. There are four phases of the problem-based learning syntax: Phase 1: Orientation to the problem, Phase 2: Organizing the students, Phase 3: Guiding group activities, and Phase 4: Concluding and formulating problem solving [27].

\section{1) Phase 1: Orientation to the problem}

One of the characteristics of problem-based learning is how to orient the students to nearby problems. In this case, the study raised the issue of plastic waste in Kampung Kramat with the contextual principle in the problem-based learning. The problem discussed must be something relevant, familiar and in accordance with the students' knowledge [28]. Explaining the problems can be done with superhero, cartoon and doll figures. The problem told in the story is actually experienced and close to daily life. In this eco-pedagogy, storytelling is a gamification feature which leads children to "missions" and the ultimate goal of a problem. Story telling is a narrative explanation that is very easy to understand by children [29].

\section{2) Phase 2: Organizing the students}

At this stage, the teacher begins to put forward the issues around the students through a storyline. Then, the students make field observations to compare what they hear (in the story) with what they see directly [30]. For example, when the character in the story sees a dirty river, the children see the same problem in their environment. This is in line with the active learning theory, where problems are discovered by the students and aimed to activate their knowledge [28]. For pre-school children, the conflict feature in the gamification is given to help them find a common problem through questions and answers.

\section{3) Phase 3: Guiding group activities}

The teamwork to resolve the issue is supported by the gamification feature to create cooperative learning. The fundamental thing in cooperative learning is that the students are engaged to each other and will not succeed without the others, are stronger, and individuals of the entire group can have a better performance [31]. Cooperative learning is important in the 
[4] Ö. Akkor and Ş. Gündüz, "The study of university students' awareness and attitude towards environmental education in Northern Cyprus," Eurasia J. Math. Sci. Technol. Educ., vol. 14, no. 3, pp. 1057-1062, 2017. believe that success exists in every single team's performance greater than their personal performance. Therefore, it is necessary to develop team skills and feedback among team members [31].

Cooperative learning will increase the capacity of each student independently. To achieve cooperative learning in problem solving for early childhood, the gamification features, such as grouping, challenge, competition, and reward, can be used. These are the game features that make the children feel like 'playing', which is the most appropriate way for them to learn [32].

These features will directly involve them across all issues that have been discovered. The "Challenge" feature can be displayed by collecting snacks or bottle waste in a given time (competition). Rewards are given to the achievement of the group in the form of symbols or badges.

4) Phase 4: Concluding and formulating problem solving

This is the phase of concluding a problem-solving effort obtained from group discussions and presentations. This stage is the review and conclusion stage. At this stage, a scorecard as the accumulated result and feedback as a conclusion are used.

\section{Closing}

In the closing activity, the teacher provides reinforcement by presenting a grading feature indicating that the students have completed a topic. This will also make them follow the next level. This closing activity emphasizes students' involvement to come in the next meeting.

\section{CONCLUSION}

The problem-based instructional design can be developed into an eco-pedagogy learning model for children aged 4-7 years, applied in Kampung Kramat Malang. In addition, gamification features can be an interesting problem-based learning approach for children. This instructional design can be used by teachers by observing the problem-based learning phases and gamification features. Gamification should be applied to each activity in the form of familiar symbols that are easy to understand to involve the students' senses. This instructional design contains basic frameworks and principles that can be developed according to the teacher's need.

\section{ACKNOWLEDGMENTS}

I am enormously grateful to LPDP (Lembaga Pengelola Dana Pendidikan-Indonesia Endowment Fund for Education) for continuous encouragement on my study and funding to participate in this conference. I am thankful for all my lecturers for kindly advices throughout my study.

\section{REFERENCES}

[1] Y. Voytenko, K. McCormick, J. Evans, and G. Schliwa, "Urban living labs for sustainability and low carbon cities in Europe: towards a research agenda," J. Clean. Prod., vol. 123, pp. 45-54, Jun. 2016.

[2] J. R. Jambeck et al., "Plastic waste inputs from land into the ocean," Science, vol. 347, no. 6223, pp. 768-771, 2015.

[3] R. M. Pink, "Indonesia: One of the Most Polluted Countries in the World," in Water Rights in Southeast Asia and India, Springer, 2016, pp. 93-118.

[5] G. W. Misiaszek, "Eco-pedagogy and Citizenship in the Age of Globalisation: connections between environmental and global citizenship education to save the planet: Eco-pedagogy and Citizenship in the Age of Globalisation: Connections Between Environmental and Global Citizenship Education to Save the Planet," Eur. J. Educ., vol. 50, no. 3, pp. 280-292, Sep. 2015.

[6] G. W. Misiaszek, Eco-pedagogy in the age of globalization: Educators perspectives of environmental education programs in the Americas which incorporate social justice models. University of California, Los Angeles, 2011.

[7] G. W. Misiaszek, "Eco-pedagogy: teaching critical literacies of 'development', 'sustainability', and 'sustainable development," Teach. High. Educ., pp. 1-18, Mar. 2019.

[8] S. Maekele, "Analysis of Globalization, the Planet and Education," Sci. Educ., p. 13.

[9] H. Hillen, A. Scherpbier, and W. Wijnen, "History of problem-based learning in medical education," Lessons Probl.-Based Learn., pp. 5-11, 2010.

[10] C. Haas and G. Ashman, "Kindergarten Children's Introduction to Sustainability through Transformative, Experiential Nature Play," Australas. J. Early Child., vol. 39, no. 2, pp. 21-29, Jun. 2014.

[11] T. L. Kingsley and M. M. Grabner-Hagen, "Gamification: Questing to Integrate Content Knowledge, Literacy, and 21st-Century Learning," $J$. Adolesc. Adult Lit., vol. 59, no. 1, pp. 51-61, 2015.

[12] R. S. Alsawaier, "Research trends in the study of gamification," Int. J. Inf. Learn. Technol., 2019.

[13] J. Hamari, J. Koivisto, and H. Sarsa, "Does Gamification Work?-A Literature Review of Empirical Studies on Gamification.," in HICSS, 2014, vol. 14, pp. 3025-3034.

[14] Ã. Hasan, S. Kanbul, and F. Ozdamli, "Effects of the gamification supported flipped classroom model on the attitudes and opinions regarding game-coding education," Int. J. Emerg. Technol. Learn. IJET, vol. 13, no. 1, pp. 109-123, 2018.

[15] M. Hitchens and R. Tulloch, "A gamification design for the classroom," Interact. Technol. Smart Educ., vol. 15, no. 1, pp. 28-45, 2018.

[16] N. B. S. Wangi, P. Setyosari, D. Kuswandi, and W. D. Dwiyogo, "Gamification as a Strategy to Improve Student Learning Motivation: Preparing Student for 21st Century," p. 4.

[17] J. A. de Oliveira, "The Effectiveness of Gamification as a ProblemBased Learning Tool on Teaching Agile Project Management," The University of Liverpool, 2016.

[18] D. Basten, "Gamification," Ieee Softw., no. 5, pp. 76-81, 2017.

[19] R. M. Branch, Instructional design: The ADDIE approach, vol. 722. Springer Science \& Business Media, 2009.

[20] T. Akbar, "Kampung Tematik sebagai Bentuk Partisipasi Masyarakat dalam Permasalahan Permukiman Kumuh di Kota Malang," vol. 70, p. 12, 2018.

[21] L. Penny, U. Bijaksana, R. Yunita, and D. Itta, "Kajian perilaku masyarakat membuang sampah di bantaran sungai martapura terhadap lingkungan perairan," EnviroScienteae, vol. 8, no. 3, pp. 117-126, 2016.

[22] T. Sekito, T. B. Prayogo, C. Meidiana, H. Shimamoto, and Y. Dote, "Estimating the flow of recyclable items and potential revenue at a waste bank: the case in Malang City, Indonesia," Environ. Dev. Sustain., vol. 21, no. 6, pp. 2979-2995, Dec. 2019.

[23] B. Lorentz, "Developmental Milestones," in Encyclopedia of Evolutionary Psychological Science, T. K. Shackelford and V. A. Weekes-Shackelford, Eds. Cham: Springer International Publishing, 2017, pp. 1-12.

[24] R. C. Richey, J. D. Klein, and M. W. Tracey, The instructional design knowledge base: Theory, research, and practice. Routledge, 2010.

[25] D. Carter, "A Nature-Based Social-Emotional Approach to Supporting Young Children's Holistic Development in Classrooms with and without Walls: The Social-Emotional and Environmental Education 
Development (SEED) Framework.," Int. J. Early Child. Environ. Educ., vol. 4, no. 1, pp. 9-24, 2016.

[26] G. Piredda, "What is an affective artifact? A further development in situated affectivity," Phenomenol. Cogn. Sci., Jun. 2019.

[27] R. Arends, "Learning to teach. New York," NY McGrow-Hill, 2012.

[28] H. G. Schmidt, J. I. Rotgans, and E. H. Yew, "The process of problembased learning: what works and why," Med. Educ., vol. 45, no. 8, pp. 792-806, 2011.

[29] N. Capuano, A. Gaeta, M. Gaeta, G. R. Mangione, and A. Pierri, "A Cultural Re-mediation Model for Storytelling in Pre-school Education," Int. J. Emerg. Technol. Learn. IJET, vol. 10, no. 7, pp. 39-46, 2015.
[30] K. R. Salim, M. Abdullah, H. N. Haron, N. H. Hussain, and R. Ishak, "A Team-Teaching Model in an Informal Cooperative Learning Classroom," Int. J. Emerg. Technol. Learn. IJET, vol. 14, no. 20, pp. 4457, 2019.

[31] K. Mohd-Yusof, S. Helmi, M.-Z. Jamaludin, and N.-F. Harun, "Cooperative problem-based learning (CPBL): A practical PBL model for a typical course," Int. J. Emerg. Technol. Learn. IJET, vol. 6, no. 3, pp. 12-20, 2011.

[32] I. P. Samuelsson and M. A. Carlsson, "The playing learning child: Towards a pedagogy of early childhood," Scand. J. Educ. Res., vol. 52, no. 6, pp. 623-641, 2008. 